\title{
Agronomic efficiency of 'Cantaloupe' melon under different water blades and organic fertilization
}

Toni Halan da Silva Irine ${ }^{1 *}$, Lucimara Ferreira de Figueredo', Janailson Pereira de Figueredo', Josimar Nogueora da Silva², Jacinto Rômulo Guedes de Paiva², Raimundo Andrade ${ }^{3}$

'Federal University of Paraiba, Areia, Brazil

${ }^{2}$ Federal Rural University of the Semi-Arid, Mossoró, Brazil

3State University of Paraíba, Catolé do Rocha, Brazil

*Corresponding author, e-mail: tonnyirineupb@hotmail.com

\begin{abstract}
The objective of this study was to evaluate the effect of different irrigation blades on the presence and absence of biofertilizer on the agronomic performance of the 'Cantaloupe' melon in the Paraíba backwoods. The work was conducted under field conditions in the Agroecology Sector, belonging to the State University of Paraíba (UEPB), Campus IV. The experimental design was a randomized block using four irrigation blades $\left(60,80,100\right.$ and $\left.120 \%-\mathrm{ET}_{0^{\prime}}\left(\mathrm{mm} \mathrm{day}^{-1}\right)\right)$ with presence and absence of biofertilizer replicated six times. The following variables were evaluated: main branch length, leaf area, number of leaves, phytomass aerial part, pulp diameter, soluble solids, bark diameter, number of seeds per fruit, seed weight per fruit and weight of 100 seeds. The irrigation blade of $120 \%$ of $\mathrm{ET}_{0}$ promoted greater growth and development since biofertilizer application provided a greater number of seeds per fruit and weight of 100 seeds, there was no interaction between the factors studied in both variables evaluated in the Cantaloupe melon.
\end{abstract}

Keywords: Cucumis melo L., development, irrigation, production.

\section{Introduction}

The melon (Cucumis melo L.) belongs to the Cucurbitaceae family and the Cantalupensis group, it is the eighth most produced fruit vegetable in the world, among the ten most exported, in the international market with the world production reaching 29.46 million tons in 2013, with the largest producers being China, Turkey and Iran, with production of approximately $14.4 ; 1.7$ and 1.5 million tons, respectively (FAO, 2015).

In Brazil, 478,431 tons of melon were produced in 18,861 hectares in 2010, providing an average yield of $25.4 \mathrm{tha}^{-1}$, with the states of Rio Grande do Norte, Ceará, Bahia and
Pernambuco standing out as the largest producers. Their contribution was about $93.3 \%$ of national production (IBGE, 2012). However, in order to obtain greater results, this crop needs to have factors managed properly, thus can provide a higher productivity. These factors include irrigation management and organic fertilization. Irrigation managementis an indispensable factor for a successful production of the melon crop, related to both terms productivity and fruit quality (Pires et al., 2013). Therefore, water deficit or water excess affects plants growth, sanity and production (Jaleel et al., 2008).

This way, the amount of water supplied to the plants has fundamental importance in 
productivity, since errors or negligence can lead to production failures, making crops economically unfeasible (Coelho et al., 2005). On the other hand, the application of adequate water levels can considerably improve their yield and reduce losses of water sources (Pereira Filho et al., 2014).

Another factor of great importance is organic fertilization, which consists in making healthy soils and crops promoting improvements in structure, aeration and soil moisture storage capacity, with a temperature regulating effect (Silva et al., 2013). Besides being an important agricultural production option to achieve a balance between increasing crop productivity and exploiting the environment (Bezerra Neto et al., 2014).

Among the sources of organic fertilizers are biofertilizers, which act on the chemical, physical and biological characteristics of soils improving their fertility, as well as on the cycling of nutrients in the soil-plant system, contributing to a better soil quality and plant productivity (Véras et al., 2014).

In this sense, studies have shown the positive effects of liquid biofertilizers on the growth, productivity and quality of melon (Marrocos, 2011; Santos, 2012).

The objective of this work was to analyze the influence of different irrigation blades on the agronomic performance of 'Cantaloupe' melon in the presence and absence of biofertilizer in the Paraíba semi-arid region.

\section{Material and methods}

The experiment was carried out under field conditions, in the Agroecology Sector of the State University of Paraíba - UEPB, Campus IV, located in the municipality of Catole do Rocha - PB, between November 2011 and February 2012, whose geographic coordinates $6^{\circ} 20^{\prime} 38$ 'S of latitude and $37^{\circ} 44^{\prime} 48^{\prime} \mathrm{W}$ of longitude The Greenwich and altitude of $275 \mathrm{~m}$. The climate of the county, according to the classification of Koppen is the BSWh type, that is warm and dry type steppe.

Soil of the experimental area was classified as Fluvic Neosol according to the Brazilian Soil Classification System (SBCS)
(EMBRAPA, 2006). At 0-20 cm depth, the following characteristics were present: $\mathrm{pH}\left(\mathrm{H}_{2} \mathrm{O}\right)=6.85 ; \mathrm{Ca}^{+}$ ${ }^{2}=2.10\left(\mathrm{cmol}_{\mathrm{c}} \mathrm{dm}^{-3}\right) ; \mathrm{Mg}^{+2}=1.07\left(\mathrm{cmol}_{\mathrm{c}} \mathrm{dm}^{-3}\right)$; $\mathrm{Na}^{+}=3.78\left(\mathrm{cmol}_{\mathrm{c}} \mathrm{dm}^{-3}\right) ; \mathrm{K}^{+}=0.01\left(\mathrm{mg} \mathrm{dm}^{-3}\right) ; \mathrm{H}=$ $0.13\left(\mathrm{cmol}_{\mathrm{c}} \mathrm{dm}^{-3}\right) ; \mathrm{Al}^{+3}=0.13\left(\mathrm{cmol}_{\mathrm{c}} \mathrm{dm}^{-3}\right) ; \mathrm{CTC}$ $=594\left(\mathrm{cmol}_{\mathrm{c}} \mathrm{dm}^{-3}\right) ; \mathrm{SB}=5.8\left(\mathrm{cmol}_{\mathrm{c}} \mathrm{dm}^{-3}\right) ; \mathrm{C} . \mathrm{O}=$ 4.55 (\%); $\mathrm{M} . \mathrm{O}=7.85$ (\%); assimilable phosphorus = $8.31 \mathrm{mg} / 100 ;$ sand $=63.90\left(\mathrm{~g} \mathrm{~kg}^{-1}\right)$; silt $=20.65(\mathrm{~g}$ $\left.\mathrm{kg}^{-1}\right)$; clay $=15.45\left(\mathrm{~g} \mathrm{~kg}^{-1}\right)$; Apparent density $=1.41$ $\left(\mathrm{g} \mathrm{cm}^{-3}\right)$; field capacity humidity $=11.23\left(\mathrm{~g} \mathrm{~kg}^{-1}\right)$; permanent wilting point humidity $=6.56\left(\mathrm{~g} \mathrm{~kg}^{-1}\right)$ and textural class $=$ sandy franc.

The experimental design was a randomized block design with four replications, distributed in a $4 \times 2$ factorial scheme, related to four irrigation blades and two types of organic fertilization, that is, the presence and absence of biofertilizers, enriched bovine biofertilizer was applied. The four irrigation blades were based on the reference evapotranspiration, being: 60 , $80,100,120 \%$ of $\mathrm{ET}_{0}\left(\mathrm{~mm} \mathrm{day}^{-1}\right)$. The quantities of water were calculated daily using the Class A tank method, installed inside the greenhouse. Calculated by Equation (1):

Where:

$$
E T O=\frac{E T C}{K P}
$$

$\mathrm{ET}_{0}$ - reference evapotranspiration $\left(\mathrm{mm}\right.$ day $\left.^{-1}\right)$;

ETC - evaporation of Class A Tank ( $\mathrm{mm}$ );

$\mathrm{Kp}$ - the coefficient of tank obtained according to Doorenbos \& Kassam (1979).

The irrigation system was located by drip irrigation, with equidistant emitters of $0.6 \mathrm{~m}$ and the average flow of $2.0 \mathrm{~L} / \mathrm{h}$, supplied through a $1.0 \mathrm{hp}$ single-phase pump, where the irrigations were carried out in a single watering (afternoon). The water used for irrigation had the following chemical characteristics: $\mathrm{pH}$ of 7.53; an electrical conductivity of $0.8\left(\mathrm{dS} / \mathrm{m}^{-1}\right)$, classified, according to Richards (1954), as $C_{3} S_{1}$. The amount of total water applied to the final stage of the crop, according to the blades, corresponding to $11,260,14,884,18,732$ and 22,467 L per plant, respectively.

The biofertilizer based on bovine manure was produced anaerobically in a plastic container with a capacity of 240 liters, containing a hose attached to a clear plastic bottle with water to remove the methane gas produced 
inside the container by the fermentation of the anaerobic bacteria. The material used to produce the referred fertilizer consisted of $70 \mathrm{~kg}$ of green manure from lactating cows, $120 \mathrm{~L}$ of water, $5 \mathrm{~kg}$ of sugar and $5 \mathrm{~L}$ of milk to accelerate the metabolism of bacteria, $4 \mathrm{~kg}$ of rock dust +5 $\mathrm{kg}$ of legume $+3 \mathrm{~kg}$ of wood ash. The macro and micronutrient contents (Table 1) were determined in the Soil Fertility Laboratory of the Federal Rural University of Pernambuco, Recife / PE.

Table 1. Results of the chemical analysis of the macro and micronutrients in the dry matter of the biofertilizer used in the cultivation of the 'Cantaloupe' melon under water blades, in the municipality of Catolé do Rocha, 2012.

\begin{tabular}{|c|c|c|c|c|c|c|c|c|}
\hline $\mathrm{pH}$ & $\mathrm{CE} \mathrm{dS} / \mathrm{m}^{-1}$ & $\mathrm{~N}$ & $P$ & $S$ & $\mathrm{Na}$ & $K$ & $\mathrm{Ca}$ & $\mathrm{Mg}$ \\
\hline & & $.9 \mathrm{Kg}^{-1}$. & ......m & $m^{-3} \ldots \ldots$ & \multicolumn{4}{|c|}{.. $\mathrm{Cmol}_{\mathrm{c}} \mathrm{dm}^{-3}$. } \\
\hline 6.03 & 8.94 & 1.40 & 445.8 & 25.75 & 1.07 & 1.98 & 13.30 & 5.05 \\
\hline
\end{tabular}

Seeds of the 'Acclaim' cultivar, from the 'Cantaloupe' group, were used to produce the seedlings, which were produced in a protected environment, in Styrofoam trays containing 128 cells, with a capacity of $0.05 \mathrm{~L}$ of earthworm humus.

Soil preparation consisted of two plowing and one harrowing, followed by the opening of the furrows, with $1 \mathrm{~kg}$ of earthworm humus per linear meter, after three days, carried out the transplantation of the spaced seedlings $2.0 \mathrm{mx}$ $0.40 \mathrm{~m}$.

From 30 days after emergence (DAE). fertilization with biofertilizer was carried out in the melon via foliage, by using a costal sprayer containing $10 \mathrm{~L}$ of water and $5 \mathrm{ml}$ of biofertilizer, applying at 8-day intervals.

The following variables were evaluated: main branch length $(\mathrm{cm})$, leaf area $\left(\mathrm{cm}^{2}\right)$, number of leaves $\left(\mathrm{n}^{\circ}\right)$, phytomass of aerial part (g), pulp diameter ( $\mathrm{mm}$ ), soluble solids ('Brix), bark diameter $(\mathrm{mm})$, number of seeds per fruit (number), weight of seeds per fruit (g) and weight of 100 seeds ( $\mathrm{g}$ ) in 'Cantaloupe' melon plants.

At the end of the experiment, $65 \mathrm{DAE}$, the CRP was measured, which was measured with a tape measure, starting from the neck at the apex of the plant, AFU was obtained by foliar measurements (width and leaf length), using a millimeter ruler, the length (C) and the width (L) were multiplied by a correction factor (HR) of 0.50 in order to have the estimation value. For the determination of this factor, the methodology suggested by Peixoto \& Peixoto (2009) was used. The (NF) consisted of counting all the leaves of the plants.

AFU, CRP and NF were determined, then the leaves and the branches were packed in paper bags and dried in a forced circulation oven at $65^{\circ} \mathrm{C}$ in the 48 hour period until reaching a constant weight. After drying, the material weighed, as a result, a dry mass was obtained from the leaf and branch, and by the sum of those two dry masses the aerial part (MSPA) was determined.

After harvest, eight fruits were randomly separated by the plot for laboratory evaluations. The fruits were split longitudinally, then with a digital caliper, the diameter of the pulp and peel was determined in the median region, in each half of the fruit. The SS ( ${ }^{\circ}$ Brix) contents were made immediately after the cuts in the fruits, four fruit slices were separated from each treatment and the pulp was removed, after homogenization of the juice, a portion of the juice was filtered, and using a portable analogical refractometer RT-280 Instrutemp (C), obtaining values in ${ }^{\circ}$ Brix (Coelho et al., 2003). For the determination of the NSF, the fruits were randomly counted from each replicate. The seeds were extracted manually after cutting the fruits and counted, the seed weight per fruit, eight fruits were collected from each replicate, and after the cut in the fruit was removed the seeds and weighed in analytical balance, being the values expressed in grams, the weight of one thousand seeds was also determined, using eight sub-samples of 100 seeds from each treatment, according to recommendations of the Rules for Seed Analysis (Brasil, 2009).

The data were submitted to analysis of variance (Test F), followed by the comparison of average by Tukey's test, using the SISVAR Computational Program version 5.0. 


\section{Results and discussion}

According to the results of the analysis of variance, we observed (Table 2) a significant effect of the irrigation blades for the variables main branch length (CRP), number of leaves (NF), bark diameter (DC), number of leaves seeds per fruit (NSF), seed weight per fruit (PSF) and weight of 100 seeds (P100S) at $1 \%$ and $5 \%$ of significance, not observing the same significant effect for the other variables analyzed. For the biofertilizer, there was a significant effect only on the variable number of seeds per fruit at $5 \%$ of significance, and no significant difference was observed in the biofertilizer for the other variables. In turn, there was no significant interaction between the factors studied $(L \times B)$.

Table 2. Summary of the analysis of variance relative to the variables: CRP - Length of main branch; AFU - Single leaf area; NF - Number of leaves; FSPA - Phytomass of aerial part; Dpolpa - Pulp diameter; SS - Soluble solids; DC - Shell diameter; NSF - Number of seeds per fruit; PSF - Seed weight per fruit and P100S - Weight of 100 seeds of 'Cantaloupe' melon plants submitted to different irrigation blades in the presence and absence of biofertilizer. Catolé do Rocha/PB, 2012.

\begin{tabular}{|c|c|c|c|c|c|c|}
\hline \multirow[t]{2}{*}{ FV } & \multirow[t]{2}{*}{ GL } & \multicolumn{5}{|c|}{ Mean squares } \\
\hline & & CRP $(\mathrm{cm})$ & $\mathrm{AFU}\left(\mathrm{cm}^{2}\right)$ & $N F\left(n^{\circ}\right)$ & FSPA (g) & DPolpa (mm) \\
\hline Blades (L) & 3 & $219.54^{* *}$ & $323.54^{\mathrm{ns}}$ & $802.04^{* *}$ & $5376.95^{\text {ns }}$ & $0.843^{\text {ns }}$ \\
\hline Linear & 1 & $624.10^{* *}$ & $140.90^{\text {ns }}$ & $2352.62^{* *}$ & $879.93^{\text {ns }}$ & $0.006^{\mathrm{ns}}$ \\
\hline Quadratic & 1 & $28.12^{\text {ns }}$ & $4.89^{n s}$ & $40.50^{\text {ns }}$ & $4511.55^{\text {ns }}$ & $0.781^{\text {ns }}$ \\
\hline Regression deviation & 2 & 6.40 & 824.69 & 40.00 & 10739.38 & 0.056 \\
\hline Biofertilizer (B) & 1 & $6.12^{\text {ns }}$ & $2550.58^{\text {ns }}$ & $162.00^{\text {ns }}$ & $386.00^{\text {ns }}$ & $0.281^{\mathrm{ns}}$ \\
\hline Interation ( $L \times B)$ & 3 & $59.20^{\text {ns }}$ & $873.54^{\text {ns }}$ & $0.08^{\text {ns }}$ & $3954.45^{\text {ns }}$ & $1.864^{\mathrm{ns}}$ \\
\hline Residue & 24 & 60.85 & 543.52 & 33.18 & 3569.85 & 1.197 \\
\hline CV (\%) & & 4.86 & 16.73 & 3.71 & 10.57 & 3.88 \\
\hline \multirow[t]{2}{*}{ FV } & $\mathrm{GL}$ & \multicolumn{5}{|c|}{ Mean squares } \\
\hline & & SS ( ${ }^{\circ}$ Brix) & $\mathrm{DC}(\mathrm{cm})$ & $\operatorname{NSF}\left(n^{\circ}\right)$ & PSF (g) & P100S (g) \\
\hline Blades (L) & 3 & $0.595^{\mathrm{ns}}$ & $1.124^{* *}$ & $5167.70^{* *}$ & $29.32^{* *}$ & $1.27^{* *}$ \\
\hline Linear & 1 & $0.115^{\mathrm{ns}}$ & $0.636^{\mathrm{ns}}$ & $5499.02^{* *}$ & $8.05^{* *}$ & $0.26^{* *}$ \\
\hline Quadratic & 1 & $0.427^{\text {ns }}$ & $2.673^{\mathrm{ns}}$ & $144.50^{* *}$ & $69.20 * *$ & $3.55^{* *}$ \\
\hline Regression deviation & 2 & 1.242 & 0.062 & 9859.60 & 10.71 & 0.01 \\
\hline Biofertilizer (B) & 1 & $0.002^{\mathrm{ns}}$ & $0.006^{\mathrm{ns}}$ & $40.50^{*}$ & $2.83^{\text {ns }}$ & $0.01^{\text {ns }}$ \\
\hline Interation $(L \times B)$ & 3 & $0.265^{\mathrm{ns}}$ & $1.33^{\text {ns }}$ & $11.08^{\mathrm{ns}}$ & $0.84^{\mathrm{ns}}$ & $0.01^{\mathrm{ns}}$ \\
\hline Residue & 24 & 1.107 & 0.525 & 8.00 & 0.85 & 0.003 \\
\hline CV (\%) & & 11.03 & 8.48 & 0.63 & 6.26 & 1.91 \\
\hline
\end{tabular}

It is observed (Figure $1 \mathrm{~A}$ and $\mathrm{IF}$ ) main branch length trends (CRP) and weight of 100 seeds (P100S) of the melon as a function of irrigation (\%), observing that the increase in volume of water provided a substantial gain of CRP and P100S, with maximum estimated value of $182 \mathrm{~cm}$ and $3.87 \mathrm{~g}$ in the $120 \% \mathrm{ET}_{0}$ blade, with increments of $20.27 \%$ and $29 \%$, respectively. In the other hand, the number of leaves (NF) and seed weight per fruit (NSF), was observed (Figure $1 B$ and $1 E$ ), that regression equation was fitted an inverse quadratic model in a function of the irrigation blades, noticing a greater number of leaves and fruit seed weight of $227^{\circ}$ and $17.25 \mathrm{~g}$ were observed in the irrigation blades of $120 \%$ and $60 \%$ of $\mathrm{ET}_{0}$, with increases of $30.45 \%$ and $43.75 \%$ respectively.

This quadratic behavior in the number of leaves and seed weight per fruit may be related to foundation fertilization with earthworm humus, in which the mineralization rate of $\mathrm{N}$ is greater, but its release is slower and gradual, and this nutrient is responsible for providing a larger leaf area of the plant and a greater weight of seeds (Harris et al., 1990). These results disagree with those found by Medeiros et al. (2012), analyzing the effect of the irrigation blade on the Toad Skin Melon, was observed the lowest production values at the irrigation level of $423 \mathrm{~mm}$.

Regarding the number of leaves the results are discordant to those obtained by Valnir Júnior et al. (2013) studying irrigation blades and frequency of application in the growth of the melon did not verify significant effects of the irrigation blades on the number of leaves per melon plant. 

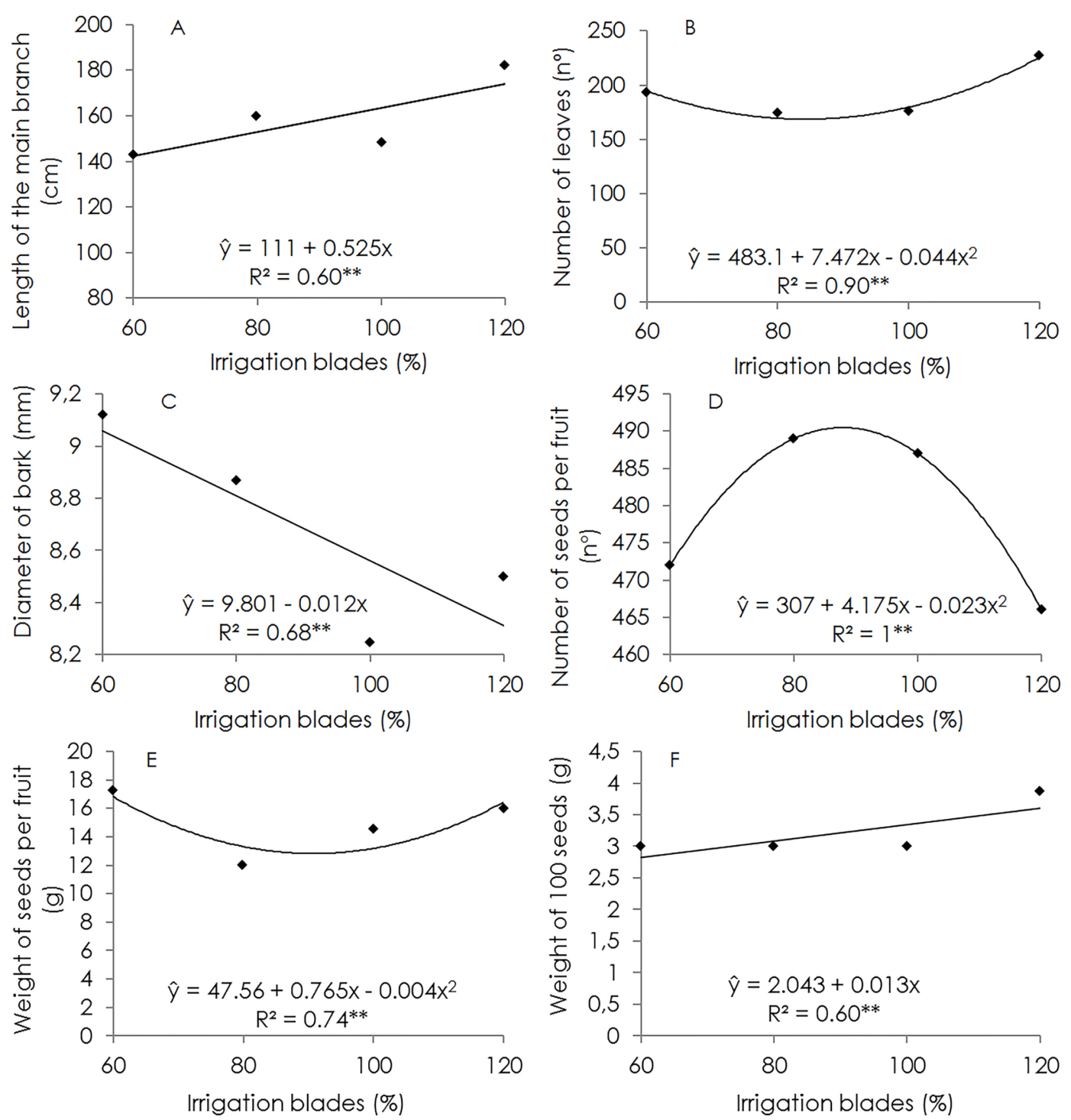

Figure 1. Length of the main branch (A) and number of leaves (B), diameter of bark (C), number of seeds per fruit (D), weight of seeds per fruit (E) and weight of 100 seeds (F) of 'Cantaloupe' melon submitted to different irrigation blades

On the other hand, the results found for the main branch length are in agreement with those verified by Ferraz et al. (2011), analyzing the morphophysiological aspects, fruit yield and water use efficiency in a protected environment, which found the highest CRP values in the highest irrigation $\mathrm{ET}_{0}$.

In Pereira Filho et al. (2014), evaluating the frequency of irrigation and application of $\mathrm{N}$ in Cantaloupe melon Imperial variety 45 irrigated by drip irrigation in the semi-arid conditions of the Northeast, was found higher values of the morphological characteristics, with main stem length of $172.07 \mathrm{~cm}$ being obtained in the irrigated treatment once a day (F1).

For the weight of 100 seeds (P100S), a significant influence was observed in the irrigation blades, adjusting to the linear model, which means that as the levels of the blades increases as weight of 100 seeds increased. The highest value was $(3.87 \mathrm{~g})$, in the $120 \% \mathrm{ET}_{0}$ blade, with a $29 \%$ increase in relation to the $60 \% \mathrm{ET}_{0}$ blade, respectively (Figure 1F).

These results are in agreement with those of Suassuna et al. (2011) studying the photochemical and productive efficiency of melon fruits cultivated under different irrigation blades, verified maximum values in the largest irrigation blades.

The diameter of the bark (DC) of the melon was influenced by the irrigation blades (Figure 1C), and it was explained by the regressive linear regression model, finding the estimated maximum value $(9.12 \mathrm{~mm})$ in the 
lowest applied blade (60\% $\left.\mathrm{ET}_{0}\right)$. A reduction of $7.29 \%$ was identified, respectively. The minimum DC values were verified on the largest irrigation blades (Figure 1C).

The low yield of bark obtained in the largest irrigation blade is related to the higher thickness of pulp obtained in the same irrigation blade. According to Queiroga et al. (2013) the thickness of the bark is a parameter considered important to determine the quality of the melon, since the percentage of fruit utilization elapses from the highest pulp/peel thickness ratio. According to Coelho et al. (2003) the greater thickness of the pulp is desirable, as it increases the weight and the edible part, improving the quality of the fruit.

In relation to the number of seeds per fruit (NSF), a significant effect is observed (Figure ID), with the equation presenting a quadratic model as a function of the irrigation blades, with a higher number of seeds (489) in the maximum blade of $90.76 \%$ of $\mathrm{ET}_{0}$, since as measure blade irrigation depth was increased, there was a decrease in the number of seeds per fruit. This behavior corresponded to the increase of $4.93 \%$, it occurred in the interval between the blade of $120 \%$ and the blade that promoted the largest number $(90.76 \%)$. These results differ from those found by Biscaro et al. (2012), where the irrigation blade affected the number of seeds, with maximum values with the irrigation blade based on $150 \%$.

This behavior can be explained possibly by the fact that the water consumption of the melon 40 days after the transplanting decreases, and perhaps the $120 \%$ applied blade has been in excess, and could have caused the leaching of nutrients and, because nitrogen is the nutrient responsible for seed production.

We can observe that the variable leaf area (AFU), dry phytomass of aerial part (FSPA), pulp diameter (Dpolpa) and soluble solids ('Brix) were not statistically influenced by water levels, according to (Table 3), even though we can notice that the $120 \% \mathrm{ET}_{0}$ blade provided values higher than the other blades studied, with values 572.30 and 29.00 for the FSPA and Dpolpa variables, with an increase of $2.52 \%$ and $4.04 \%$ respectively. According to Siqueira et al. (2009) the pulp of the fruit should be thick and the small internal cavity promoting a greater resistance to the transport and handling, it was verified that the increase of the irrigation blades promoted a larger diameter of pulp and a smaller thickness of the bark.

In relation to the soluble solids (SS), it was observed that as the irrigation blades increased, a reduction in the SS content occurred, obtaining the highest SS content (9.75\%) in the lowest blade studied. According to Sales Júnior et al. (2006), melons with a content of SS less than $9 \%$ are considered non-marketable because this attribute does not increase after harvesting, however, this SS content found in this work is considered as marketable fruit.

This reduction of the SS content of the fruits is due to the dilution of the sugars in their tissues by the influence of the increase in the amount of water applied to the plants at the time of fruit maturation (Pinheiro Neto et al., 2007).

Table 3. Estimated means relative to the variables: AFU - Unit leaf area; FSPA - dry phytomass of aerial part; Dpolpa - Diameter of the pulp and SS - Soluble solids of 'Cantaloupe' melon plants submitted to different irrigation blades. Catolé do Rocha / PB, 2012.

\begin{tabular}{lllll}
\hline \multicolumn{4}{l}{ Treatments } & \multicolumn{4}{l}{ Table of averages } \\
\hline \multirow{3}{*}{ Blade $\left(\mathrm{L}_{1}\right) 60 \%$} & AFU $\left(\mathrm{cm}^{2}\right)$ & FSPA $(\mathrm{g})$ & Dpolpa $(\mathrm{mm})$ & SS $\left({ }^{\circ}\right.$ Brix $)$ \\
\cline { 2 - 5 } Blade $\left(\mathrm{L}_{2}\right) 80 \%$ & $133.87 \mathrm{a}$ & $558.23 \mathrm{a}$ & $27.87 \mathrm{a}$ & $9.75 \mathrm{a}$ \\
Blade $\left(\mathrm{L}_{3}\right) 100 \%$ & $145.62 \mathrm{a}$ & $562.92 \mathrm{a}$ & $28.25 \mathrm{a}$ & $9.00 \mathrm{a}$ \\
Blade $\left(\mathrm{L}_{4}\right) 120 \%$ & $133.87 \mathrm{a}$ & $567.61 \mathrm{a}$ & $28.37 \mathrm{a}$ & $9.50 \mathrm{a}$ \\
\hline${ }^{*}$ Means followed by the same letter in the column do not differ statistically from each other by the Tukey test at 5\% probability
\end{tabular}

The following data regarding the research disagree with those found by Valnir Júnior et al. (2013), when studying irrigation blades and frequency of application on melon

growth, was obtained results superior to that of the research, observing that the application of the irrigation blade total splitted in two times a day was the one that presented the greatest 
accumulation of dry matter of the part aerial with $28.34 \mathrm{~cm}^{2}$ plant ${ }^{-1}$.

However, Terceiro Neto et al. (2013) evaluating the productivity and quality of melon under management with increasing salinity water, found a significant effect for the combination of saltwater management strategies, obtaining total soluble solids values of $11.80 \%$, higher than those found in the present which was $9.75 \%$, provided by the Blade $\left(L_{1}\right) 60 \%$.

Regarding the effects of the biofertilizer on the production, it was observed that the application of the biofertilizer presented significant effects at $5 \%$ of significance by the Tukey test, on the number of seeds per fruit and weight of 100 seeds, providing results of 478 and increase of $1.70 \%$ in relation to $\left(B_{0}\right)$ for the number of seeds per fruit and $3.25 \mathrm{~g}$ and increase of $2.20 \%$ in relation to $\left(B_{0}\right)$ for the weight of 100 seeds, this higher production can be attributed to the adequate supply and availability of nutrients supplied to the soil through the composition of the biofertilizer (Table 4).

Table 4. Estimated means relative to variables: CRP - Length of main branch; NF - Number of leaves; AFU - Single leaf area; FSPA - dry phytomass of aerial part; Dpolpa - Pulp diameter; DC - bark diameter; SS - Soluble solids; NSF Number of seeds per fruit; PSF - Seed weight per fruit and P100S - Weight of 100 seeds of 'Cantaloupe' melon plants with and without biofertilizer. Catolé do Rocha / PB, 2012.

\begin{tabular}{|c|c|c|c|c|c|}
\hline \multirow{2}{*}{ Treatments } & \multicolumn{4}{|c|}{ Average table } & \multirow[b]{2}{*}{ Dpolpa (mm) } \\
\hline & CRP $(\mathrm{cm})$ & $N F\left(n^{\circ}\right)$ & AFU $\left(\mathrm{cm}^{2}\right)$ & FSPA (g) & \\
\hline With biofertilizer $\left(\mathrm{B}_{1}\right)$ & $23.17 a$ & $203 a$ & $148.28 a$ & $610.65 a$ & $28.68 a$ \\
\hline Without biofertilizer $\left(B_{0}\right)$ & $22.84 a$ & $181 a$ & $130.42 a$ & $608.21 \mathrm{a}$ & $28.06 a$ \\
\hline \multirow[t]{2}{*}{ Treatments } & Average $\dagger$ & & & & \\
\hline & $\mathrm{DC}(\mathrm{cm})$ & SS ( ${ }^{\circ}$ Brix) & NSF $\left(n^{\circ}\right)$ & PSF (g) & P100S (g) \\
\hline With biofertilizer $\left(B_{1}\right)$ & $8.5 a$ & $9.37 a$ & $478 a$ & $15.25 a$ & $3.25 a$ \\
\hline Without biofertilizer $\left(\mathrm{B}_{0}\right)$ & $8.06 a$ & $9.12 a$ & $470 b$ & $14.62 a$ & $3.18 b$ \\
\hline
\end{tabular}

Cavalcante et al. (2012) warn that biofertilizer is a viable alternative to the partial or supplemental supply of nutrients to the plants. According to Freire et al. (2011) biofertilizer can reduce soil moisture losses and can also reduce water consumption and increase crop productivity. Several authors have stated that the addition of manure, organic compounds and biofertilizers in the soil improves soil fertility, not only by the simple supply of organic matter to the soil, but by attenuating the negative effects of soil acidity and alkalinity (Mesquita et al., 2007; Alves et al., 2009).

However, it is observed that the plants that received biofertilizer application were superior to those plants that did not receive organic fertilization (Table 4). The data related to the research corroborate with the results found by Marrocos (2011) studying the composition of biofertilizer and its use via fertirrigation in melon, in the characteristics of soluble solids ('Brix), observed that the shot of biofertilizer did not influence the culture of the melon. According to Ribeiro et al. (2014) evaluating the application of organic and mineral sources in the development and production of melon in the southern state of Piauí, was found lower values in relation to the results of the present research, where the values of leaf numbers and soluble solids were considered low since the international market requires at least 9 ('Brix) (Oliveira et al., 2006).

This similar behavior among the variables studied in relation to the application of biofertilizer may possibly be explained by the availability of the nutrients in the nutrient solution of the biofertilizer, because when diluting the biofertilizer their nutrient contents possibly decrease considerably, as we can mention the phosphorus that is a nutrient responsible for the growth of the plant, thus not influencing the growth and production of the melon.

\section{Conclusions}

The $120 \% \mathrm{ET}_{0}$ irrigation blade promoted greater growth and development of the 'Cantaloupe' melon.

The application of biofertilizer provided a higher number of seeds per fruit and weight of 100 seeds of the 'Cantaloupe' melon. 
Irrigation blades and the application of biofertilizer did not interfere in the production and fruit quality of the 'Cantaloupe' melon.

\section{References}

Alves, G.S., Santos, D., Silva, J.A., Nascimento, J.A.M., Cavalcante, L.F., Dantas, T.A.G. 2009. Estado nutricional do pimentão cultivado em solo tratado com diferentes tipos de biofertilizantes. Acta Scientiarum 31: 661-665.

Bezerra Neto, F., Oliveira, L.J., Santos, A.P., Lima, J.S.S., Silva, I. N. 2014. Otimização agroeconômica da cenoura fertilizada com diferentes doses de jitirana. Revista Ciência Agronômica 45: 305-311.

Biscaro, G.A., Vaz, M.A., Giacon, G.M., Gomes, E.P., Silva, S.B., Motomiya, A.V.A. 2012. Produtividade de duas cultivares de mamona submetidas a diferentes lâminas de irrigação suplementar. Revista Brasileira de Engenharia Agrícola e Ambiental 16: 925-930.

BRASIL. 2009. Ministério da Agricultura, Pecuária e Abastecimento. Regras para análise de sementes. Brasilia: Mapa/ACS. 399 p.

Cavalcante, L.F., Pereira, W.E., Curvêlo, C.R.S., Nascimento, J.A.M., Cavalcante, I.H.L. 2012. Estado nutricional de pinheira sob adubação orgânica do solo. Ciência Agronômica 43: 579588.

Coelho, E.F., Coelho Filho, M.A., Oliveira, S.L. 2005. Agricultura irrigada: eficiência de irrigação e de uso de água. Bahia Agrícola, v.7: 57-60.

Coelho, E.L., Fontes, P. C.R., Finger, F.L., Cardoso, A.A. 2003. Qualidade do fruto de melão rendilhado em função de doses de nitrogênio. Bragantia, 62: 173-178.

Doorenbos, J., Kassam, A.H. 1979. Yield response to water. Rome: FAO, 193p. Irrigation and Drainage Paper 33.

EMBRAPA. Empresa Brasileira de Pesquisa Agropecuária. 2006. Sistema brasileiro de classificação de solos. Centro Nacional de Pesquisa de Solos/Embrapa Solos. Rio de Janeiro, Brasil. 306 p.

FAO. Food and Agriculture Organization of the United Nations. 2015. http://faostat.fao.org/ <Acesso em 18 Fev. 2015>

Ferraz, R.L.S., Melo, A.S., Ferreira, R.S., Dutra, A.F., Figueredo, L.F. 2011. Aspectos morfofisiológicos, rendimento e eficiência no uso da água do meloeiro "Gália" em ambiente protegido. Ciência Agronômica 42: 957-964.

Freire, J.L.O., Cavalcante, L.F., Rebequi, A.M., Dias, T.J., Souto, A.G.L. 2011. Necessidade hídrica do maracujazeiro-amarelo cultivado sob estresse salino, biofertilização e cobertura do solo. Caatinga 24: 82-91.

HARRIS, G.D., PLATT, W.L., PRICE, B.C. 1990. Vermicomposting in a rural community. Biocycle 10: $48-51$.

IBGE. Instituto Brasileiro de Geografia e Estatística. $2012 . \quad \mathrm{http} / / / \mathrm{www}$.sidra.ibge.gov.br/bda/ <Acesso em $18 \mathrm{Fev} .2015>$

Jaleel, C.A., Gopi, R., Sankar, B., Gomathinayagam, M., Panneerservam, R. 2008. Differential responses in water use efficiency in two varieties of Catharantus roseus under drought stress. Comptes Rendus Biologie 331: 42-47.

Marrocos, S.D.T.P. 2011. Composição de biofertilizante e sua utilização via fertirrigação em meloeiro. 62f. (Dissertação de Mestrado) - Universidade Federal Rural do Semi-Árido, Mossoró, Brasil.

Medeiros, J.F., Aroucha, E.M.M., Dutra, I., Chaves, S.W.P., Souza, M.S. 2012. Efeito da lâmina de irrigação na conservação pós-colheita de melão Pele de Sapo. Horticultura Brasileira 30: 51 4-519.

Mesquita, E.F., Cavalcante, L.F., Gondim, S.C., Cavalcante, Í.H.L., Araújo, F.A.R., Cavalcante, M.Z.B. 2007. Produtividade e qualidade de frutos do mamoeiro em função de tipos e doses de biofertilizantes. Semina: Ciências Agrárias 28: 589596.

Oliveira, F.J.M., Amaro Filho, J., Moura Filho, E.R. 2006. Efeito da adubação orgânica sobre a qualidade de frutos de meloeiro (Cucumis melo L.). Revista Verde 1: 81-85.

Peixoto, C.P., Peixoto, M.F.S.P. 2009. Dinâmica do crescimento vegetal: princípios básicos. Tópicos em Ciências Agrárias, 38 p.

Pereira Filho, J.V., Bezerra, F.M.L., Silva, A.R.A., Sousa, C.C.M., Castro, J.M. 2014. Frequência de irrigação e aplicação de $\mathrm{N}$ em meloeiro irrigado por gotejamento nas condições semiáridas do Nordeste. Científica 42: 11-22.

Pinheiro Neto, L.G., Viana, T.V.A., Azevedo, B.M., Freitas, J.A.D., Souza, V.F. 2007. Produção e qualidade dos frutos de meloeiro submetido a redução hídrica na fase final do ciclo. Irriga 12: 54-62.

Pires, M.M.M.L., Santos, H.A., Santos, D.F., Vasconcelos, A.S., Aragão, C.A. 2013. Produção do meloeiro submetido a diferentes manejos de água com o uso de manta de tecido não tecido. Horticultura Brasileira 31: 304-310.

Queiroga, F.M., Novo Junior, J., Costa, S.A.D., Oliveira Filho, Pereira. F.H.F., Souzaz, A.L., 
Maracaja, P.B. 2013. Produção e qualidade de frutos de melão Harper em função de doses de boro, Agropecuária Científica no Semi-Árido 9: 87-93.

Ribeiro, S.A., Matias, S.S.R., Sousa, R.R., Alixandre, T.F., Oliveira, W.S. 2014. Aplicação de fontes orgânicas e mineral no desenvolvimento e produção do melão no sul do Estado do Piauí. Revista Verde 9: 320-325.

Richards, L.A. 1954. Diagnosis and improvement of saline and alkali soils. US Department of Agriculture, Washington, USA. 160 p. (USDA Agricultural Handbook, 60).

Sales Júnior, R., Dantas, F.F., Salviano, A.M., Nunes, G.H.S. 2006. Qualidade do melão exportado pelo porto de Natal-RN. Ciência Rural 36: 286-289.

Santos, A.P.G. 2012. Influências de biofertilizantes nos teores foliares de macronutrientes, nas trocas gasosas, na produtividade e na pós-colheita da cultura do melão. 95f. (Dissertação de Mestrado) - Universidade Federal do Ceará, Fortaleza, Brasil.

Silva, M. L., Bezerra Neto, F., Linhares, P.C.F., Bezerra, A.K.H. 2013. Produção de cenoura fertilizada com flor-de-seda (Calotropis procera (Ait.) R.Br.). Ciência Agronômica 44: 732-740.

Siqueira, W.C., Faria, L.A., Lima, E.M.C., Rezende, F.C., Gomes, L.A.A., Custódio, T.N. 2009. Qualidade de frutos de melão amarelo cultivado em casa de vegetação sob diferentes lâminas de irrigação. Ciência e Agrotecnologia 33: 10411046.

Suassuna, J.F., Melo, A.S., Costa, F.S., Fernandes, P.D., Ferreira, R.S., Sousa, M.S.S. 2011 . Eficiência fotoquímica e produtiva de frutos de meloeiro cultivado sob diferentes lâminas de irrigação. Semina: Ciências Agrárias, Londrina 32: 12511262.

Terceiro Neto, C.P.C.T., Gheyi, H.R., Medeiros, J.F., Dias, N.S., Campos, M.S. 2013. Produtividade e qualidade de melão sob manejo com água de salinidade crescente. Pesquisa Agropecuária Tropical 43: 354-362.

Valnir Júnior, M.V., Lima, V.L.A., Gomes Filho, R.R., Carvalho, C.M., Soares, F.A.L., Lima, S.C.R.V. 2013. Lâminas de irrigação e frequência de aplicação no crescimento do meloeiro. Agricultura Irrigada 7: $42-53$

Véras, M.L.M., Araújo, D.L., Alves, L.S., Andrade, A.F., Andrade, R. 2014. Aplicação de biofertilizante e húmus de minhoca em plantas de cajueiro. Terceiro Incluído 4: 30-40. 